\title{
CHEMO-BIOCATALYTIC ONE-POT TWO- STEP CONVERSION OF CYCLIC AMINE TO LACTAM USING WHOLE CELL MONOAMINE OXIDASE
}

Petra Zajkoska $^{1 *}$, Max Cárdenas-Fernández², Gary J. Lye ${ }^{2}$, Michal Rosenberg ${ }^{1}$, Nicholas J. Turner $^{3}$, Martin Rebroš ${ }^{1}$

${ }^{1}$ Department of Biochemical Technology, Faculty of Chemical and Food Technology, Slovak University of Technology, Slovakia

*current affiliation: CEA, IG, Genoscope, UMR8030, France

${ }^{2}$ The Advanced Centre for Biochemical Engineering, Department of Biochemical Engineering, University College London, United Kingdom

${ }^{3}$ School of Chemistry, Manchester Institute of Biotechnology, University of Manchester, Manchester, United Kingdom

Corresponding author: Martin Rebroš

Address: Radlinského 9, 81237 Bratislava, Slovakia

e-mail: martin.rebros@stuba.sk

phone: +421 (2) 59325480

fax: +421 (2) 52493198

Short running title: Chemo-Bio Lactam 


\section{ABSTRACT}

The research in the area of one-pot chemoenzymatic cascades is rapidly progressing. However, most of the biocatalysts currently involved in this field are pure enzymes, while whole cells and crude enzyme extracts remain unexplored. The main goal of this work is the development of a chemo-biocatalytic one-pot two-step system involving whole cell monoamine oxidase (MAO) coupled with a $\mathrm{Cu}$-based oxidative system $\left(\mathrm{CuI} / \mathrm{H}_{2} \mathrm{O}_{2}\right)$ for the transformation of 1,2,3,4-tetrahydroisoquinoline (THIQ) to 3,4-dihydroisoquinolin-1(2H)one (DHIO). For the biological oxidative step, MAO-N variants D9 and D11 were tested in the form of whole cell and crude lysate biocatalysts. Among these, whole E. coli OverExpress C43(DE3) cells expressing MAO-N D9 with the following kinetic parameters $V_{\max }=36.58 \mathrm{mM} / \mathrm{h}, K_{M}=8.124 \mathrm{mM}-$ showed the best performance and were employed in combination with the chemical catalysis step in a sequential one-pot two-step process. A stepwise feeding strategy was applied to produce the intermediate 3,4-dihydroisoquinoline (DHIQ). The biotransformation was scaled-up to the initial volume of $25 \mathrm{ml}$ and after triple THIQ feeding, $48.2 \mathrm{mM}$ DHIQ was reached with a yield of $71.3 \%$. At this stage, chemical catalysts ( $1 \mathrm{~mol} \% \mathrm{CuI}$ and 10 eq. $\mathrm{H}_{2} \mathrm{O}_{2}$ ) were added to the biologically produced DHIQ, which was transformed to $\sim 30 \mathrm{mM}$ DHIO at a $69.4 \%$ overall yield. As MAO-N variants have wide substrate specificity, this work broadens the portfolio of one-pot chemoenzymatic processes employing whole cell biocatalysts, representing an alternative to using pure enzymes.

Keywords: chemo-biocatalysis, monoamine oxidase, cascade reaction, whole cell biocatalysts. 


\section{INTRODUCTION}

The idea of combining enzymes with suitable chemical catalysts in one-pot reactions has been a focus of researchers to a large extent over the past 10 years as one of the tools for producing interesting and valuable substances under mild conditions. One-pot processes benefit from the fact that usually there is no need for intermediate recovery, purification steps and the use of protective groups or reagents (Schoevaart and Kieboom 2002); therefore, several operational steps are omitted. In the pioneering work in this field, glucose isomerase was combined with a heterogeneous platinum catalyst for the one-pot conversion of a mixture of D-glucose and D-fructose into D-mannitol in aqueous conditions. It was the first time the compatibility of chemo- and biocatalysis was demonstrated in a tandem one-pot process (Makkee et al. 1980). Biocatalysis is, nowadays, a partner, rather than a rival of the chemocatalysts. Since biocatalysts usually operate in aqueous environments, and thus contribute to replacing organic solvents, applying enzymes and whole cells to particular chemical processes might reduce their E-factors, which represent the environmental compatibility and complexity of the synthesis (Woodley 2008). Gröger and Hummel (2014) reviewed the currently-known one-pot processes in aqueous medium, combining metal/organocatalysis with biocatalysis. Although tandem and sequential one-pot reactions with bio- and chemocatalysts broaden the portfolio of organic synthesis, it is noteworthy to say that whole cells are rather an exception (Ema et al. 2008; Fuchs et al. 2011; Liu et al. 2009; Szymanski et al. 2010) and mostly free enzymes have been involved in these processes. However, whole cells are used in $75 \%$ of industrially implemented redox biotransformations, when often cofactor regeneration is necessary and/or the enzyme is not stable outside the cell. Generally, whenever whole cells can be used, the process is economically more attractive compared to the use of isolated enzymes (Carballeira et al. 2009; Solano et al. 2012).

Enantioselective recombinant mutants of monoamine oxidase MAO-N have been derived from the same wild-type sequence by directed evolution combined with rational design and 
high-throughput screening methods (Ghislieri et al. 2013a; 2013b; Heath et al. 2014; Turner 2009; Turner 2011). By deracemization of a broad range of amine substrates facilitated by MAO-N, a variety of intermediates and structure motifs for the pharmaceutical and agrochemical industries are produced, including boceprevir for the treatment of hepatitis $\mathrm{C}$ (Li et al. 2012). The production of chiral amines from racemic mixtures of primary (Alexeeva et al. 2002), secondary (Carr et al. 2003) and tertiary (Dunsmore et al. 2006) amines is performed as a one-pot chemo-biocatalysed reaction involving MAO-N for the stereoselective oxidative step and usually amine borane complex as the non-specific reducing agent, although recently a new way for deracemization has been proposed by combining amine oxidase and imine reductase enabling one-pot process performance (Heath et al. 2016). The MAO-N variants D9 and D11 differ by a single point mutation (H430G), which results in the increased active site volume of the D11 variant, allowing for the binding of sterically demanding substrates (Ghislieri et al. 2013a; 2013b).

1,2,3,4-tetrahydroisoquinolines and 3,4-dihydroisoquinoline-1(2H)-ones were identified as potent and selective inhibitors of Kinase insert Domain containing Receptor (KDR). Small molecules inhibiting KDR kinase activity might prospectively be used in the clinic to treat human tumors (Choquette et al. 2008).

The aim of this work is to develop a one-pot chemo-biocatalytic transformation of the amine 1,2,3,4-tetrahydroisoquiniline to the lactam 3,4-dihydroisoquinoline-1(2H)-one using whole cells expressing MAO-N in combination with $\mathrm{CuI} / \mathrm{H}_{2} \mathrm{O}_{2}$ in order to produce a structure pattern that might potentially be further used in the synthesis of KDR inhibitors.

\section{MATERIALS AND METHODS}

\section{Microorganisms}


Monoamine oxidase mutants MAO-N D9 and MAO-N D11, harbored in plasmid pET16b, were developed and kindly provided by the team of Prof. Nicholas Turner (Manchester Institute of Biotechnology, University of Manchester, UK). The plasmids were transformed to three different E. coli strains of chemically competent cells: BL21(DE3) Gold (Stratagene, NL), Lemo21(DE3) (New England Biolabs, CA) and OverExpress C43(DE3) (Lucigen, USA), according to manufacturers' protocols. Preliminary small-scale expression studies to select the best strain for MAO-N expression were performed according to the manufacturers' recommendations, followed by SDS-PAGE detection of protein expression and activity testing (section Biotransformation). Protein quantification was carried out using the Bradford method with bovine serum albumin as a standard.

\section{Biomass production and expression of MAO-N}

Unless stated otherwise, all chemicals were purchased from Sigma Aldrich and the solvents were of HPLC grade. Besides the small-scale preliminary expression studies, larger cell batches (especially of E. coli OverExpress C43(DE3)) were produced in an autoinduction medium according to Schrittwieser et al. (2014) procedures. The stock solutions were sterilised separately and were mixed to get the proper composition of the medium prior to inoculation. The inoculum was prepared in LB medium (10 g/L tryptone, $5 \mathrm{~g} / \mathrm{L}$ yeast extract, $10 \mathrm{~g} / \mathrm{L} \mathrm{NaCl}$ ) containing $100 \mu \mathrm{g} / \mathrm{mL}$ ampicillin from the pre-inoculation overnight culture at $37{ }^{\circ} \mathrm{C}$ and $250 \mathrm{rpm}$. When the $\mathrm{OD}_{600 \mathrm{~nm}}$ was in the range of $0.6-1,400 \mathrm{~mL}$ of the autoinduction medium in $2 \mathrm{~L}$ Erlenmeyer flasks was inoculated with $1 \%(v / v)$ of the inoculation culture. For the first $20 \mathrm{~h}$, the cultivation was performed in the rotatory shaker at $30{ }^{\circ} \mathrm{C}$ and $150 \mathrm{rpm}$ in the presence of $100 \mu \mathrm{g} / \mathrm{mL}$ ampicillin, and then the temperature was lowered to $25{ }^{\circ} \mathrm{C}$. The overall cultivation time was $70-72 \mathrm{~h}$. The biomass was centrifuged (2750 g, $30 \mathrm{~min}, 4^{\circ} \mathrm{C}$ ), and the pellet was resuspended in $1 / 10$ th of the original volume in 
potassium phosphate buffer $(0.1 \mathrm{M}, \mathrm{pH} 7.8)$ and centrifuged again. The biomass was stored at $-20{ }^{\circ} \mathrm{C}$ until use.

\section{Cell lysates preparation}

$2 \mathrm{~mL}$ of the fermentation broth of known $\mathrm{OD}_{600}$ were centrifuged $\left(4942 \mathrm{~g}, 4{ }^{\circ} \mathrm{C}, 15 \mathrm{~min}\right)$. The pellet was re-suspended in $400 \mu \mathrm{L}$ potassium phosphate buffer $(0.1 \mathrm{M}, \mathrm{pH} 7.8)$ and the cell suspension was sonicated for $10 \mathrm{on} / \mathrm{off}$ cycles of 10 seconds at an amplitude of $10 \mu \mathrm{m}$ using the Soniprep 150 sonicator (MSE, Sanyo, Japan). If a higher amount of lysate was required, the volumes were proportionally higher. The lysate was centrifuged (4942 g, $\left.4{ }^{\circ} \mathrm{C}, 15 \mathrm{~min}\right)$ and the supernatant was used for further analysis.

\section{Biotransformation}

1,2,3,4-tetrahydroisoquinoline (THIQ, 95\%, Sigma Aldrich) was selected as the model substrate for biological oxidation using MAO-N as a biocatalyst. Probably due to spontaneous oxidation, THIQ contains $\sim 2.5 \%$ 3,4-dihydroisoquinoline (DHIQ), which was not taken into account in the calculations. To obtain $10 \mathrm{~mL}$ of the $100 \mathrm{mM}$ substrate stock solution,

131.4 $\mu \mathrm{L}$ THIQ was dissolved in $1.32 \mathrm{~mL} N, N$-dimethylformamide (DMF) and MOPS buffer (0.1 M, pH 7.8), and the $\mathrm{pH}$ was adjusted to 7.8 with $85 \%$ phosphoric acid. The small scale biotransformation with either the whole cells or with the cell lysate was performed in $50 \mathrm{~mL}$ falcon tubes in a MOPS buffer $(0.1 \mathrm{M}, \mathrm{pH} 7.8)$ at $37^{\circ} \mathrm{C}$ and $250 \mathrm{rpm}$. For the whole cells, the concentration of the biocatalyst was $6.83 \mathrm{mg}$ of the dry cell weight $\left(\mathrm{mg}_{\mathrm{DCw}}\right)$ per $\mathrm{mL}$ of reaction. The cell lysate was produced using the same amount of dry cell weight as was used for the whole cell biotransformation. If not stated otherwise, the total reaction volume was $2.6 \mathrm{~mL}$. The consumption of THIQ and the formation of DHIQ were monitored by HPLC analysis. 
For the determination of kinetic parameters, biotransformations with $2.3,5.3,10.8,21.4$, 31.8, 41.8 and $48 \mathrm{mM}$ THIQ were performed in duplicates following the above mentioned procedure and the initial reaction rates were calculated. The mean initial rates of the duplicates were calculated and plotted, with the error bars representing the standard deviation. Kinetic parameters $\mathrm{V}_{\max }$ and $\mathrm{K}_{\mathrm{M}}$ were calculated using the Prism 5 software (GraphPad Software, Inc., CA, USA).

\section{Optimization of the chemical step}

For the individual testing of the chemical reaction, separate from the biological step, commercially available 3,4-dihydroisoquinoline (DHIQ, 97.5\%, Sigma Aldrich) was used as the substrate. To make $40 \mathrm{mM}$ of the stock solution, $51.2 \mu \mathrm{L}$ DHIQ was dissolved in $510 \mu \mathrm{L}$ DMF and MOPS (0.1 M, pH 7.8) in a $10 \mathrm{~mL}$ volumetric flask. The reaction was performed in a $50 \mathrm{~mL}$ falcon tube at $37^{\circ} \mathrm{C}$ and $250 \mathrm{rpm}$ in $2 \mathrm{~mL}$ volume with $20 \mathrm{mM}$ substrate in a MOPS buffer $(0.1 \mathrm{M}, \mathrm{pH} 7.8)$. The $40 \mathrm{mM}$ stock solution of $\mathrm{CuI}$ was prepared by dissolving $76 \mathrm{mg}$ of $\mathrm{CuI}$ in $10 \mathrm{~mL}$ acetonitrile. To find the optimal ratio of $\mathrm{CuI}$ and $\mathrm{H}_{2} \mathrm{O}_{2}$, the following combinations were tested for the oxidation of DHIQ to the lactam 3,4-dihydroisoquinoline1(2H)-one (DHIO): $1 \mathrm{~mol} \% \mathrm{CuI}(10 \mu \mathrm{L}$ of the stock solution, $0.0004 \mathrm{mmol})$ and 10 eq. $\mathrm{H}_{2} \mathrm{O}_{2}$ (39 $\mu \mathrm{L}$ of the $35 \%$ solution, $0.4 \mathrm{mmol}) ; 0.5 \mathrm{~mol} \% \mathrm{CuI}(5 \mu \mathrm{L}$ of the stock solution, $0.0002 \mathrm{mmol})$ and 10 eq. $\mathrm{H}_{2} \mathrm{O}_{2} ; 0.5 \mathrm{~mol} \% \mathrm{CuI}$ and 5 eq. $\mathrm{H}_{2} \mathrm{O}_{2}(19.5 \mu \mathrm{L}$ of the $35 \%$ solution, $0.2 \mathrm{mmol})$. The reactions were performed in duplicates, of which the mean and standard deviation were calculated and plotted.

\section{Stability studies}

To test the effect of chemocatalysts $\left(\mathrm{CuI}\right.$ and $\left.\mathrm{H}_{2} \mathrm{O}_{2}\right)$ on the biocatalyst, stability studies were performed on both cells and lysates of MAO-N D9 and D11 variants. Four sets of reaction mixtures, each of total volume $3.36 \mathrm{~mL}$, were set in $50 \mathrm{~mL}$ falcon tubes at $37{ }^{\circ} \mathrm{C}$ and 250 
rpm. Except for the MOPS buffer $(0.1 \mathrm{M}, \mathrm{pH} 7.8)$ and the biocatalyst, one contained $1 \mathrm{~mol} \%$ $\mathrm{CuI}(21 \mu \mathrm{L}$ of $40 \mathrm{mM}$ stock solution, $0.00084 \mathrm{mmol})$ and the other, 10 eq. $\mathrm{H}_{2} \mathrm{O}_{2}(81.9 \mu \mathrm{L}$ of $35 \%$ solution, $0.84 \mathrm{mmol}$ ), while the third contained a combination of $1 \mathrm{~mol} \% \mathrm{CuI}+10 \mathrm{eq}$. $\mathrm{H}_{2} \mathrm{O}_{2}$, and the last one was left as a control without chemical factors. The amount of chemical agents was calculated for the volume sufficient for 3.5 reactions with $20 \mathrm{mM}$ substrate. The concentration of the biocatalyst was equal for the whole cells and the cell lysate and accounted for $6.83 \mathrm{mg}_{\mathrm{DCW}}$ per $\mathrm{mL}$ of reaction.

$1.2 \mathrm{~mL}$ standard biotransformations were performed with all setups containing $\mathrm{CuI}(1 \mathrm{~mol} \%$, $0.00024 \mathrm{mmol}), \mathrm{H}_{2} \mathrm{O}_{2}$ (10 eq, $0.24 \mathrm{mmol}$ ) or both after two, four, and $24 \mathrm{~h}$ of incubation as follows: $960 \mu \mathrm{L}$ of reaction mixture were taken from the stock and $240 \mu \mathrm{L}$ of $100 \mathrm{mM}$ THIQ stock were added to reach the $20 \mathrm{mM}$ initial substrate concentration. The biotransformation with the control setup without $\mathrm{CuI}$ and $\mathrm{H}_{2} \mathrm{O}_{2}$ was performed at the beginning of the incubation $(\mathrm{t}=0 \mathrm{~h})$ and after $24 \mathrm{~h}$. Samples taken after $3 \mathrm{~h}$ of the biotransformation were analyzed using HPLC.

\section{Intermediate product inhibition}

The MAO-N D9 cell stock was re-suspended in the MOPS buffer $(0.1 \mathrm{M}, \mathrm{pH} 7.8)$ to reach a $5 \mathrm{x}$ more concentrated suspension than what was required for the biotransformation $\left(6.83 \mathrm{mg}_{\mathrm{DCw}} / \mathrm{mL}\right)$. The amine (THIQ) stock solution was prepared as mentioned above. $5 \mathrm{~mL}$ of $90 \mathrm{mM}$ imine intermediate product (DHIQ) stock solution was prepared by dissolving $57.6 \mu \mathrm{L}$ DHIQ in $580 \mu \mathrm{L}$ DMF and the MOPS buffer $(0.1 \mathrm{M}, \mathrm{pH} 7.8)$. Prior to starting the biotransformation with $20 \mathrm{mM}$ THIQ, the cell suspension in MOPS was incubated in $50 \mathrm{~mL}$ falcon tubes for $15 \mathrm{~min}$ with the particular amount of imine to reach 10, 20, 30 and $40 \mathrm{mM}$ final concentration in $2.6 \mathrm{~mL}$ total volume of the reaction mixture. By adding the substrate, the biomass concentration was adjusted to $6.83 \mathrm{mg}_{\mathrm{DCw}} / \mathrm{mL}$ and standard biotransformations 
in duplicates were performed at $37^{\circ} \mathrm{C}$ and $250 \mathrm{rpm}$. The mean values of the initial rates were calculated and plotted, with the error bars representing standard deviations.

\section{One-pot two step reaction scale-up}

The reaction setup (Error! Reference source not found.) was scaled-up to an initial volume of $25 \mathrm{~mL}$ and was performed in $250 \mathrm{~mL}$ baffled shake flasks at $37{ }^{\circ} \mathrm{C}$ and $250 \mathrm{rpm}$. The MAO-N D9 cell stock was re-suspended in the MOPS buffer $(0.1 \mathrm{M}, \mathrm{pH} 7.8)$ to reach $5 \mathrm{x}$ concentrated suspension, which was further diluted by adding MOPS and a portion of the 100 $\mathrm{mM}$ THIQ stock. The biological step was started with a $25 \mathrm{~mL}$ reaction volume at standard conditions (biomass concentration $6.83 \mathrm{mg}_{\mathrm{DCW}} / \mathrm{mL}, 20 \mathrm{mM}$ THIQ). After three, six and nine hours, the reaction mixture was supplemented with an amount of $100 \mathrm{mM}$ THIQ stock needed to reach $20 \mathrm{mM}$, taking into account the increasing reaction volume, irrespective of the remaining substrate from the previous feeding. At each substrate feeding point, the reaction mixture was supplemented with an adequate portion of cells $\left(\mathrm{g}_{\mathrm{DCW}}\right)$ corresponding to the amount that was taken out during the sampling in order to keep the amount (not the concentration) of the biocatalyst constant. The reaction was monitored over time and after 25 $\mathrm{h}$, the shake flasks were removed from the shaker and stored at $4{ }^{\circ} \mathrm{C}$ overnight. Taking into account the volume of the chemical agents, a portion of the reaction mixture was removed and the chemical step was started with $45 \mathrm{mM}$ biologically produced DHIQ, $1 \mathrm{~mol} \% \mathrm{CuI}$ (11.25 $\left.\mu \mathrm{L} / \mathrm{mL}_{\text {reaction }}\right)$ and 10 eq. $\mathrm{H}_{2} \mathrm{O}_{2}\left(43.9 \mu \mathrm{L} / \mathrm{mL}_{\text {reaction }}\right)$. The reaction ran for $24 \mathrm{~h}$ and was monitored by HPLC.

\section{Insert Figure 1.}

\section{Analytical method}

$150 \mu \mathrm{L}$ samples were taken from the reaction mixture. The reaction was quenched by adding $150 \mu \mathrm{L} 0.5 \%(v / v)$ trifluoracetic acid (TFA), followed by intensive vortexing and centrifugation (16060 g, $10 \mathrm{~min})$. The samples were diluted with the aqueous mobile phase so 
that the concentration of each of the analyzed substances was in the range of their calibration curves. Both the biological and chemical reaction steps were monitored via HPLC using the Dionex Ultimate 3000 system equipped with the Ultimate 3000 pump, an autosampler, a UM $3000 \mathrm{RS}$ variable wavelength detector, and an ACE 5 C18 column $(150 \mathrm{~mm} \times 4.6 \mathrm{~mm}, 5 \mu \mathrm{m}$ particle size; Advance Chromatography Technologies, Aberdeen, UK). MilliQ water and methanol, both containing $0.1 \%$ TFA $(v / v)$, were used as mobile phases. The gradient analysis was performed according to the conditions in Error! Not a valid bookmark selfreference. at $30{ }^{\circ} \mathrm{C}$ at a constant flow rate of $1 \mathrm{~mL} / \mathrm{min}$. The injection volume was $20 \mu \mathrm{L}$ and the analytes were detected at $260 \mathrm{~nm}$. The quantitative analysis was performed by integration of peak areas using the external standard method. DHIO standard (98\%) was purchased from NovoChemy Ltd. (Shanghai, China). The THIQ, DHIQ and DHIO retention times were 7.1 min, 4.2 min and 13.3 min respectively.

Insert Table I.

\section{RESULTS AND DISCUSSION}

\section{Selection of the expression strain}

MAO-N variants have previously been expressed both in BL21(DE3) (Bechi et al. 2014; Ghislieri et al. 2013a; Köhler et al. 2010) and C43(DE3) cells (Ghislieri et al. 2013b; Heath et al. 2016; Schrittwieser et al. 2014). The preliminary studies focused on the selection of the host strain for the highest MAO-N D9 and MAO-N D11 expression. Based on the SDSPAGE analysis, no obvious overexpression of MAO was observed in Lemo21(DE3) and BL21(DE3) Gold strains cultivated according to the manufacturers' instructions, nor in the autoinduction medium (data not shown). Both the whole cells and the crude cell lysate of Lemo21(DE3) strain showed almost no activity towards THIQ. Although there was some MAO-N D9 expression in BL21(DE3) Gold strain (MAO-N D11 was not tested) cultivated in 
the autoinduction medium, as confirmed by the conversion of THIQ to DHIQ, it was not satisfactory. Only about $41 \%$ and $30 \%$ yield was reached after $23 \mathrm{~h}$ of $20 \mathrm{mM}$ THIQ biotransformation, performed with cells cultivated for $71 \mathrm{~h}$ and the corresponding lysate, respectively. Much better performance in terms of DHIQ yield was observed with the $E$. coli OverExpress C43(DE3) strain cultivated in the autoinduction medium. Three sets of samples were taken at 21,46 and $72 \mathrm{~h}$ of cultivation. To choose the best biocatalyst for further experiments, biotransformation of $20 \mathrm{mM}$ THIQ in $2.9 \mathrm{~mL}$ of the total reaction volume was performed with both MAO-N D9 and D1 1 cells and lysates. After $3 \mathrm{~h}$ of biotransformation, the DHIQ yield shows a difference between the two forms of the biocatalyst (whole cells, cell lysate), as well as the effect of the length of cultivation on MAO expression (Figure 10). The highest imine yield, $\sim 91 \%$ (cells) and $~ 94 \%$ (lysate), was obtained with MAO-N D9 that had been expressed for $72 \mathrm{~h}$.

\section{Insert Figure 2.}

Although there is only a single point mutation between MAO-N variants D9 and D11, there are significant differences in the performance between them, leading to the selection of the D9 variant for further studies on this reaction model. Moreover, the results obtained with the whole cells and lysate of MAO-N D9 variant are similar. As the difference between the amount of DHIQ obtained with MAO-N D9 expressed for 46 and $72 \mathrm{~h}$ are just very slight, additional information was needed to determine the suitable length of cultivation. Samples for $\mathrm{OD}_{600 \mathrm{~nm}}$ and the protein analysis were taken in several stages of growth, at which the dry cell weight was also calculated. The difference in this parameter in terms of biomass yield $\left(3.91 \pm 0.07 \mathrm{~g}_{\mathrm{DCW}} / \mathrm{L}\right.$ at $46 \mathrm{~h}$ and $4.89 \pm 0.30 \mathrm{~g}_{\mathrm{DCW}} / \mathrm{L}$ at $\left.72 \mathrm{~h}\right)$ was decisive for the cultivation time to be $72 \mathrm{~h}$. The increase in MAO-N D9 expression over time was also proven by SDSPAGE (Figure 11).

Insert Figure 3. 
Considering the costs of biocatalyst production in terms of process scale-up, the aim is to minimize the enzyme purification and operate the process with the crudest form of catalyst possible (Pollard and Woodley 2007). Although almost the same amount of DHIQ was obtained with MAO-N D9 cells and lysate during each stage of cultivation (Figure 10), in order to keep the process simple and avoid the number of procedures, MAO-N D9, in the form of whole cells harvested after $72 \mathrm{~h}$, was selected as a biocatalyst for further use.

\section{The effect of $\mathrm{CuI} / \mathrm{H}_{2} \mathrm{O}_{2}$ on the biocatalyst}

The decision for MAO-N D9 cells to be the biocatalyst of choice for the combination with the chemocatalytic step was also supported by stability studies in the presence of $\mathrm{CuI} / \mathrm{H}_{2} \mathrm{O}_{2}$ performed on the first reaction step of Error! Reference source not found.. Bechi et al. (2014) used pure MAO-N D9 for the one-pot two-step cascade conversion of cyclic amine (THIQ) to lactam (DHIO). However, no lactam formation was observed when MAO-N D9 whole cells and cell lysate were used for this model chemo-biotransformation, in combination with $\mathrm{CuI} / \mathrm{H}_{2} \mathrm{O}_{2}$, when all the reagents were mixed in one-pot at the beginning of the reaction. Therefore, the investigation of the effect of $\mathrm{CuI}, \mathrm{H}_{2} \mathrm{O}_{2}$ and their combination on the MAO-N D9 cells and cell lysate was performed. After 2, 4 and $24 \mathrm{~h}$ of incubation of the biocatalyst with $\mathrm{CuI}, \mathrm{CuI}+\mathrm{H}_{2} \mathrm{O}_{2}$ and $\mathrm{H}_{2} \mathrm{O}_{2}$, standard biotransformation with $20 \mathrm{mM}$ THIQ was performed. For comparison, control biotransformations were run with the cells and the lysate at $\mathrm{t}=0 \mathrm{~h}$ and after $24 \mathrm{~h}$ of incubation at $37^{\circ} \mathrm{C}$ and $250 \mathrm{rpm}$. Samples were taken after $3 \mathrm{~h}$ of biotransformation and the amount of formed imine was compared (Figure 12). While the incubation in the presence of 10 eq. $\mathrm{H}_{2} \mathrm{O}_{2}$ had almost no effect on the amount of formed imine by MAO-N D9 cells, it was lowered by half in the presence of $1 \mathrm{~mol} \% \mathrm{CuI}$. In both cases, the contact time did not play a significant role and almost the same amount of imine was formed after 2 and $24 \mathrm{~h}$ of incubation (Figure 12A), indicating that $\mathrm{CuI}$ probably causes deactivation of the biocatalyst in less than $2 \mathrm{~h}$. The combination of $1 \mathrm{~mol} \% \mathrm{CuI}$ and $10 \mathrm{eq}$. 
$\mathrm{H}_{2} \mathrm{O}_{2}$ had the most harmful effect on MAO-N D9 cells, and only 4.6 mM DHIQ was formed after $2 \mathrm{~h}$ incubation. In contrast to the cells, not more than $1.2 \mathrm{mM}$ DHIQ was reached with MAO-N D9 lysate that was previously incubated with the chemical agents (Figure 12B), excluding the lysate from further studies. As shown above, MAO-N D9 is sensitive to CuI and $\mathrm{H}_{2} \mathrm{O}_{2}$. Unlike the cell lysate, cell membranes of the intact whole cells protect the intracellular enzyme and diminish the negative impact of the chemicals.

Insert Figure 4.

\section{The ratio of $\mathrm{CuI}$ and $\mathrm{H}_{2} \mathrm{O}_{2}$}

When pure MAO-N D9 was used as a biocatalyst in the reaction (Fig. 1), only the amount of $\mathrm{H}_{2} \mathrm{O}_{2}$ was optimized and the best results were reached with 10 eq. (Bechi et al. 2014). Unlike CuI, $\mathrm{H}_{2} \mathrm{O}_{2}$ itself does not negatively affect the activity of MAO-N D9 cells, even after $24 \mathrm{~h}$ incubation. It is obvious that the combination of $\mathrm{CuI}$ and $\mathrm{H}_{2} \mathrm{O}_{2}$ is very harmful for the biocatalyst, even at $2 \mathrm{~h}$ of contact (Figure 12.Figure 12A). Three combinations of $\mathrm{CuI}$ and $\mathrm{H}_{2} \mathrm{O}_{2}$ were tested in order to find their optimal ratio and possibly lower the amount for the transformation

of $20 \mathrm{mM}$ commercially available DHIQ to lactam (DHIO), which is the desired final product. The reaction was performed in duplicates in $50 \mathrm{~mL}$ falcon tubes with a $2 \mathrm{~mL}$ total reaction volume and was monitored over time. The highest concentration of DHIO was reached when $1 \mathrm{~mol} \% \mathrm{CuI}$ and 10 eq. $\mathrm{H}_{2} \mathrm{O}_{2}$ were used (Figure 13).

\section{Insert Figure 5.}

After $25 \mathrm{~h}$ of reaction, the concentration of formed DHIO did not significantly increase compared to $4 \mathrm{~h}$, and reached $13.5 \pm 3.6 \mathrm{mM}\left(1 \mathrm{~mol} \% \mathrm{CuI}+10\right.$ eq. $\left.\mathrm{H}_{2} \mathrm{O}_{2}\right), 7.8 \pm 0.1 \mathrm{mM}$ ( $0.5 \mathrm{~mol} \% \mathrm{CuI}+10$ eq. $\left.\mathrm{H}_{2} \mathrm{O}_{2}\right)$, and $6.4 \pm 0.2 \mathrm{mM}\left(0.5 \mathrm{~mol} \% \mathrm{CuI}+0.5\right.$ eq. $\left.\mathrm{H}_{2} \mathrm{O}_{2}\right)$. Despite the negative effect of the chemical agents on the biocatalyst, in order to keep the reaction 
effective, it was not possible to lower their amount, as the best results were reached with $1 \mathrm{~mol} \% \mathrm{CuI}$ and 10 eq. $\mathrm{H}_{2} \mathrm{O}_{2}$.

\section{Kinetic parameters determination of MAO-N D9 cells}

As MAO-N D9 is a relatively new variant of monoamine oxidase (Rowles et al. 2012), so far only one kinetic study has been performed with the pure enzyme in the one-pot deracemization of the alkaloid ( \pm )-crispine A (Rowles et al. 2012). In our study, E. coli OverExpress C43(DE3) cells expressing MAO-N D9 were selected as the biocatalyst to be used in the one-pot two-step conversion of cyclic amine to lactam. The initial rates were calculated for the standard biotransformations with a THIQ concentration in the range of 2.3$48.0 \mathrm{mM}$, representing the amount of formed DHIQ per unit time. The results were plotted (Figure 14) and analysed using the Prism 5 software (GraphPad Software, Inc., CA, USA), and fitted well the Michaelis-Menten model with the following kinetic parameters: $\mathrm{V}_{\max }=36.58 \mathrm{mM} / \mathrm{h}$ and $\mathrm{K}_{\mathrm{M}}=8.124 \mathrm{mM}\left(\mathrm{R}^{2}=0.9843\right)$.

\section{Insert Figure 6.}

Rios-Solis et al. (2015) used the advantage of a microscale high throughput screening platform to screen the substrate specificity and kinetic parameters for the MAO-N variant D5 towards various secondary amines. The obtained $\mathrm{K}_{\mathrm{M}}$ values were of the same order of magnitude as our result. Generally speaking, the amine inhibition is the main factor affecting the overall reaction rate and for the purpose of the reaction scale-up it has been suggested to fed-batch the amine substrate. Similar behavior is assumed for the MAO-N D9.

\section{Intermediate product (DHIQ) inhibition}

Previous studies performed with the MAO-N variant D5 indicate that the forming cyclic imine product causes inhibition and inactivation of the biocatalyst (Ramesh and Woodley 2014), although the imine inhibition constants are 1-2 orders of magnitude higher than the 
corresponding substrate inhibition constants (Rios-Solis et al. 2015). Another example of irreversible imine inhibition was observed during boceprevir synthesis using the MAON401 variant, after $0.8 \mathrm{mM}$ imine already caused a $40 \%$ decrease of activity over time. The inhibition issues were overcome by optimizing the substrate feeding and addition of bisulfite to achieve a trapping of the imine product (Kohls et al. 2014; Li et al. 2012). It was assumed that imine inhibition might also be the reason why the model reaction could not be performed with whole cells as a one-pot two-step cascade with all the reagents mixed from the beginning of the reaction, as it was possible with the pure enzyme in the study of Bechi et al. (2014). Therefore, an inhibition study using commercially available imine DHIQ was performed. The biocatalyst was incubated in the presence of DHIQ (11.0, 21.7, 31.8 and 42.5 $\mathrm{mM}$ ) for $15 \mathrm{~min}$ prior to starting the standard biotransformation with $20 \mathrm{mM}$ THIQ. The effect of imine on the biological step of the model reaction was expressed as a relative initial rate compared to the control experiment performed without the addition of DHIQ to the reaction, corresponding to a $100 \%$ initial rate. The results prove that the intermediate imine product has an inhibitory effect on MAO-N D9, even at low concentrations and after a short contact time, resulting in an almost $50 \%$ decrease of the initial rate at $21.7 \mathrm{mM}$ DHIQ and more than a $70 \%$ decrease at $42.5 \mathrm{mM}$ DHIQ (Figure 15 ).

Insert Figure 7.

\section{One-pot two-step chemo-biocatalyzed reaction}

As mentioned before, the direct conversion of amine to lactam via one-pot chemobiocatalysis is not possible when MAO-N D9 whole cells are used, and it is necessary to perform the reactions stepwise. The biotransformation step with $20 \mathrm{mM}$ THIQ as a substrate was scaled-up to $250 \mathrm{~mL}$ baffled shake flasks and the reaction was started with an initial volume of $25 \mathrm{~mL}$ and biomass concentration $6.83 \mathrm{mg} \mathrm{gCw}_{\mathrm{D}} / \mathrm{mL}$. In order to shorten the contact time of the biocatalyst with high substrate concentration and following the recommendation 
of Rios-Solis et al. (2015) to avoid amine inhibition, feeding strategy was applied during the production of DHIQ. Triple feeding with $20 \mathrm{mM}$ THIQ was performed three, six and nine hours from the start, while the amount of biocatalyst was kept constant by adding the amount of cells that was taken out during the sampling, accounting for $6 \%, 4.5 \%$, and $3.8 \%$, respectively. The feeding intervals and the amount of added substrate was a compromise between the empirical knowledge about the length of the biotransformation with fresh biocatalyst ( $\sim 3 \mathrm{~h})$, the already known inhibition effect of DHIQ and the aim to effectively and conveniently produce as much DHIQ as possible. After $25 \mathrm{~h}$ of biotransformation, the concentration of DHIQ reached $48.2 \mathrm{mM}$ and the overall yield was $71.3 \%$ (

A). The overall yield was calculated as the ratio of micromoles of produced DHIQ to the total amount of micromoles of added THIQ.

Insert Figure 8.

Following the biological production of DHIQ, its chemical conversion to DHIO was employed as a second step in the one-pot system by adding $1 \mathrm{~mol} \% \mathrm{CuI}$ and 10 eq. $\mathrm{H}_{2} \mathrm{O}_{2}$ without removing the biocatalyst (Fig. 8B). The amount of chemical reagents was calculated to correspond to $45 \mathrm{mM}$ imine. This step was performed in the same parallel reaction vessels in which DHIQ was produced. The reaction was monitored for $25 \mathrm{~h}$ and the results indicate that more than $70 \%$ of DHIO was formed in the first five hours, to reach a final concentration of $\sim 30 \mathrm{mM}$ after $25 \mathrm{~h}$ (Error! Reference source not found.). The residual THIQ from the first step remains unaffected in the mixture, and therefore was not involved in the overall yield. This was calculated as the ratio of micromoles of formed DHIO to micromoles of initial DHIQ in the mixture, accounting for $69.4 \%$.

Bechi et al. (2014) reached 69\% conversion of $40 \mathrm{mM}$ THIQ to DHIO in a one-pot two-step reaction, employing $0.4 \mathrm{mg} / \mathrm{mL}$ pure MAO-N D9, where all of the reactants were mixed together from the beginning of the process. In our case, when MAO-N D9 cells were used, although still performed in one-pot, it was necessary to separate the bio- and chemocatalytical 
step due to intermediate product inhibition of the biocatalyst and its instability in the presence of the chemical catalysts. Therefore, it would be misleading to express the conversion directly from THIQ. As Bechi et al. (2014) demonstrated, the same lactam product could be produced in $94 \%$ conversion by also coupling pure MAO-N D9 with E. coli expressing xanthine dehydrogenase. Compared to the previous study, we scaled-up the reaction and modified the analytical method, which has allowed simplification of the sample work up by omitting the extraction step to DMC followed by drying. During the chemical step of the reaction, a loss of cell integrity was observed, as there was almost no pellet present in the samples taken after a couple of hours of reaction and their work up. Despite the inhibition/inactivation effect of the chemical agents, the advantage of this model reaction is the compatibility of reaction conditions for both steps, which are performed at a mild temperature and $\mathrm{pH}$ in a buffer aqueous environment. This is more typical for concurrent one-pot chemoenzymatic processes (Denard et al. 2013).

Despite the different nature of bio- and chemocatalysts, there are ways that they complement each other and work in similar conditions. There is no general model or prediction for the interactions between chemical catalysts and enzymes, as they depend individually on the characteristics of the two catalysts, as well as of the reaction being catalyzed (Denard et al. 2013). When it comes to compatibility issues, compartmentalization is one of the ways to minimize the mutual toxic interactions of the bio- and chemocatalyst. One of the options is to separate them in different liquid phases (e.g. ionic liquids) or to isolate them by supporting on organic or inorganic solid-state materials (Marr and Liu 2011). In the latter case, their reusability might be achieved. Although a chemical catalyst was not involved, in a recent study, we proved that when immobilized, MAO-N whole cells could be repeatedly used for the biotransformation of the model secondary amine (Zajkoska et al. 2015).

Coupling of bio- and chemocatalyzed reactions opens new horizons in the synthesis of valuable intermediates and recent studies have proven that MAO-N is a very suitable and 
perspective experimental model to be used in cascade reactions. One of the most recent works involved MAO-N whole cells in bio-chemo-bio one-pot transformation of racbenzylisoquinolines to $(S)$-berbines. The $(R)$-selective MAO-N D11 variant was cascadecombined with morpholine $\mathrm{BH}_{3}$ (acting as non-selective reducing agent) and berberine bridge enzyme (catalyzing the $(S)$-enantioselective $\mathrm{C}-\mathrm{C}$ bond formation) as an example of how two flavin-dependant oxidases of opposite enantioselectivity, acting on different parts of the benzylisoquinoline substrate, could be combined in one-pot (Schrittwieser et al. 2014). A novel combination of two important amine synthesis biocatalysts - transaminases and MAO$\mathrm{N}$ variants - was used under compatible conditions for the regio- and stereoselective synthesis of chiral 2,5-disubstituted pyrrolidine building blocks, as well as for the deracemization and dealkylation of a range of methylbenzylamine derivatives. Taking into account the broad substrate specificity of MAO-N variants, there are examples of one-pot chemo-biocatalytic cascades involving transaminase, MAO-N and a non-selective reducing agent (O'Reilly et al. 2014a; O'Reilly et al. 2014b; O'Reilly and Turner 2015). In addition to the conventional one-pot processes, engineered biometallic E. coli cells combining nanoscale bioreduced $\mathrm{Pd}(0)$ particles and a MAO-N D5 variant in a single organism were used to for the deracemization of 1-methyltetrahydroisoquinoline (MTQ) to (R)-MTQ via an imine intermediate. The two reactions were performed separately in one vessel using hydrogen as an electron donor in the reduction step (Foulkes et al. 2011). This is a novel approach to using synthetic biology tools in the development of organisms for multistep chemobiocatalyzed one-pot reactions involving not only MAO.

\section{Conclusion}

In this study, we demonstrated a one-pot two-step conversion of cyclic amine to lactam employing whole cells that express MAO-N coupled with a $\mathrm{Cu}$-based oxidative system. Taking into account that MAO-N variants have an affinity towards a variety of amine 
substrates, this proves the concept that the whole cell biocatalyst can be competitive with a pure enzyme and advantageous in terms of scale-up. Compared to pure enzymes, several operational steps are omitted in the production of the biocatalyst.

\section{Acknowledgement}

The research leading to these results has received funding from the European Union Seventh Framework Programme BIONEXGEN under grant agreement no. 266025. This work was cofunded by the Slovak Research and Development Agency under contract no. DO7RP0042-11 and by the Slovak Grant Agency for Science VEGA 2/0090/16. Petra Zajkoska is grateful for the scholarship awarded by the National Scholarship Programme of the Slovak Republic and the funding provided by the Department of Biochemical Engineering supporting her research stay at UCL. 


\section{References}

Alexeeva M, Enright A, Dawson MJ, Mahmoudian M, Turner NJ. 2002. Deracemization of $\alpha$-methylbenzylamine using an enzyme obtained by in vitro evolution. Angew Chem Int Ed Engl 41(17):3177-3180.

Bechi B, Herter S, McKenna S, Riley C, Leimkuhler S, Turner NJ, Carnell AJ. 2014. Catalytic bio-chemo and bio-bio tandem oxidation reactions for amide and carboxylic acid synthesis. Green Chem 16(10):4524-4529.

Carballeira JD, Quezada MA, Hoyos P, Simeo Y, Hernaiz MJ, Alcantara AR, Sinisterra JV. 2009. Microbial cells as catalysts for stereoselective red-ox reactions. Biotechnol Adv 27(6):686-714.

Carr R, Alexeeva M, Enright A, Eve TS, Dawson MJ, Turner NJ. 2003. Directed evolution of an amine oxidase possessing both broad substrate specificity and high enantioselectivity. Angew Chem Int Ed Engl 42(39):4807-10.

Denard CA, Hartwig JF, Zhao H. 2013. Multistep one-pot reactions combining biocatalysts and chemical catalysts for asymmetric synthesis. ACS Catal 3(12):2856-2864.

Dunsmore CJ, Carr R, Fleming T, Turner NJ. 2006. A chemo-enzymatic route to enantiomerically pure cyclic tertiary amines. J Am Chem Soc 128(7):2224-2225.

Ema T, Ide S, Okita N, Sakai T. 2008. Highly efficient chemoenzymatic synthesis of methyl $(R)$-o-chloromandelate, a key intermediate for clopidogrel, via asymmetric reduction with recombinant Escherichia coli. Adv Synth Catal 350(13):2039-2044.

Foulkes JM, Malone KJ, Coker VS, Turner NJ, Lloyd JR. 2011. Engineering a biometallic whole cell catalyst for enantioselective deracemization reactions. Acs Catal 1(11):1589-1594. 
Fuchs M, Schober M, Pfeffer J, Kroutil W, Birner-Gruenberger R, Faber K. 2011. Homoallylic alcohols via a chemo-enzymatic one-pot oxidation-allylation cascade. Adv Synth Catal 353(13):2354-2358.

Ghislieri D, Green AP, Pontini M, Willies SC, Rowles I, Frank A, Grogan G, Turner NJ. 2013a. Engineering an enantioselective amine oxidase for the synthesis of pharmaceutical building blocks and alkaloid natural products. J Am Chem Soc 135(29):10863-10869.

Ghislieri D, Houghton D, Green AP, Willies SC, Turner NJ. 2013b. Monoamine oxidase (MAO-N) catalyzed deracemization of tetrahydro- $\beta$-carbolines: Substrate dependent switch in enantioselectivity. ACS Catal 3(12):2869-2872.

Gröger H, Hummel W. 2014. Combining the 'two worlds' of chemocatalysis and biocatalysis towards multi-step one-pot processes in aqueous media. Curr Opin Chem Biol 19(0):171-179.

Heath RS, Pontini M, Bechi B, Turner NJ. 2014. Development of an $R$-selective amine oxidase with broad substrate specificity and high enantioselectivity. ChemCatChem 6(4):996-1002.

Heath RS, Pontini M, Hussain S, Turner NJ. 2016. Combined Imine Reductase and Amine Oxidase Catalyzed Deracemization of Nitrogen Heterocycles. ChemCatChem $8(1): 117-120$.

Choquette D, Teffera Y, Polverino A, Harmange J-C. 2008. Discovery of novel 1,2,3,4tetrahydroisoquinolines and 3,4-dihydroisoquinoline-1(2H)-ones as potent and selective inhibitors of KDR: Synthesis, SAR, and pharmacokinetic properties. Bioorg Med Chem Lett 18(14):4054-4058.

Köhler V, Bailey KR, Znabet A, Raftery J, Helliwell M, Turner NJ. 2010. Enantioselective biocatalytic oxidative desymmetrization of substituted pyrrolidines. Angew Chem Int Ed Engl 49(12):2182-4. 
Kohls H, Steffen-Munsberg F, Höhne M. 2014. Recent achievements in developing the biocatalytic toolbox for chiral amine synthesis. Curr Opin Chem Biol 19(0):180-192.

Li T, Liang J, Ambrogelly A, Brennan T, Gloor G, Huisman G, Lalonde J, Lekhal A, Mijts B, Muley S and others. 2012. Efficient, chemoenzymatic process for manufacture of the Boceprevir bicyclic [3.1.0]proline intermediate based on amine oxidase-catalyzed desymmetrization. J Am Chem Soc 134(14):6467-72.

Liu S, Rebros M, Stephens G, Marr AC. 2009. Adding value to renewables: a one pot process combining microbial cells and hydrogen transfer catalysis to utilise waste glycerol from biodiesel production. Chem Commun(17):2308-2310.

Makkee M, Kieboom APG, Van Bekkum H, Roels JA. 1980. Combined action of enzyme and metal catalyst, applied to the preparation of D-mannitol. J Chem Soc, Chem Commun(19):930-931.

Marr AC, Liu SF. 2011. Combining bio- and chemo-catalysis: from enzymes to cells, from petroleum to biomass. Trends Biotechnol 29(5):199-204.

O'Reilly E, Iglesias C, Ghislieri D, Hopwood J, Galman JL, Lloyd RC, Turner NJ. 2014a. A regio- and stereoselective $\omega$-transaminase/ monoamine oxidase cascade for the synthesis of chiral 2,5-disubstituted pyrrolidines. Angew Chem Int Ed 53(9):24472450.

O'Reilly E, Iglesias C, Turner NJ. 2014b. Monoamine Oxidase- $\omega$-Transaminase Cascade for the Deracemisation and Dealkylation of Amines. ChemCatChem 6(4):992-995.

O'Reilly E, Turner NJ. 2015. Enzymatic cascades for the regio- and stereoselective synthesis of chiral amines. Perspect Sci 4(0):55-61.

Pollard DJ, Woodley JM. 2007. Biocatalysis for pharmaceutical intermediates: the future is now. Trends Biotechnol 25(2):66-73.

Ramesh H, Woodley JM. 2014. Process characterization of a monoamine oxidase. J Mol Catal B: Enzym 106(0):124-131. 
Rios-Solis L, Mothia B, Yi S, Zhou Y, Micheletti M, Lye GJ. 2015. High throughput screening of monoamine oxidase (MAO-N-D5) substrate selectivity and rapid kinetic model generation. J Mol Catal B: Enzym 120:100-110.

Rowles I, Malone KJ, Etchells LL, Willies SC, Turner NJ. 2012. Directed rvolution of the enzyme monoamine oxidase (MAO-N): Highly efficient chemo-enzymatic deracemisation of the alkaloid ( \pm )-crispine A. ChemCatChem 4(9):1259-1261.

Schoevaart R, Kieboom T. 2002. Combined catalytic conversion involving an enzyme, a homogeneous and a heterogeneous catalyst: One-pot preparation of 4-deoxy-Dglucose derivatives from D-galactose. Tetrahedron Lett 43(18):3399-3400.

Schrittwieser JH, Groenendaal B, Resch V, Ghislieri D, Wallner S, Fischereder EM, Fuchs E, Grischek B, Sattler JH, Macheroux P and others. 2014. Deracemization By Simultaneous Bio-oxidative Kinetic Resolution and Stereoinversion. Angew Chem Int Ed Engl 53(14):3731-4.

Solano DM, Hoyos P, Hernaiz MJ, Alcantara AR, Sanchez-Montero JM. 2012. Industrial biotransformations in the synthesis of building blocks leading to enantiopure drugs. Bioresour Technol 115:196-207.

Szymanski W, Postema CP, Tarabiono C, Berthiol F, Campbell-Verduyn L, De Wildeman S, De Vries JG, Feringa BL, Janssen DB. 2010. Combining designer cells and click chemistry for a one-pot four-step preparation of enantiopure $\beta$-hydroxytriazoles. Adv Synth Catal 352(13):2111-2115.

Turner NJ. 2009. Directed evolution drives the next generation of biocatalysts. Nat Chem Biol 5(8):567-73.

Turner NJ. 2011. Enantioselective oxidation of C-O and C-N bonds using oxidases. Chem Rev 111(7):4073-87.

Woodley JM. 2008. New opportunities for biocatalysis: making pharmaceutical processes greener. Trends Biotechnol 26(6):321-327. 
Zajkoska P, Rosenberg M, Heath R, Malone KJ, Stloukal R, Turner NJ, Rebroš M. 2015. Immobilised whole-cell recombinant monoamine oxidase biocatalysis. Appl Microbiol Biotechnol 99(3):1229-36. 
Table I. Mobile phase gradient for the quantification of THIQ, DHIQ and DHIO

\begin{tabular}{ccc}
\hline t (min) & MilliQ + 0.1\% TFA & MeOH + 0.1\% TFA \\
\hline $0-10$ & 85 & 15 \\
$10-10.5$ & 30 & 70 \\
$10.5-15.5$ & 20 & 80 \\
$15.5-16$ & 0 & 100 \\
$16-18$ & 0 & 100 \\
$18-18.5$ & 85 & 15 \\
$18.5-20.5$ & 85 & 15
\end{tabular}




\section{List of figures}

Figure 1. One-pot two-step chemo-biocatalytic conversion of 1,2,3,4-tetrahydroisoquinoline (THIQ) to 3,4-dihydroisoquinolin-1(2H)-one (DHIO) via imine (DHIQ) intermediate.

Figure 2 Imine (DHIQ) formed from $20 \mathrm{mM}$ THIQ at $\mathrm{t}=3 \mathrm{~h}$ by MAO-N D9 and MAO-N D11 in form of E. coli OverExpress C43(DE3) cells and lysate from the equal amount of cells harvested at 21 (white bars), 46 (grey bars) and 72 (black bars) hours of cultivation.

Figure 3. SDS-PAGE of E. coli OverExpress C43(DE3) expressing MAO-N D9 (55 kDa) cultivated in autoinduction media over time. Lanes: molecular weight standard (1);7.5 h (2); 21 h (3); 26 h (4); 31 h (5); 46 h (6); 54.5 h(7); 72 h (8).

Figure 4. The effect of $1 \mathrm{~mol} \% \mathrm{CuI}, 10$ eq. $\mathrm{H}_{2} \mathrm{O}_{2}$ and their combination on MAO-N D9 cells (A) and lysate (B) after $0,2,4$ and $24 \mathrm{~h}$ incubation. The results represent the amount of formed imine (DHIQ) after $3 \mathrm{~h}$ biotransformation of $20 \mathrm{mM}$ THIQ at $37{ }^{\circ} \mathrm{C}$ and $250 \mathrm{rpm}$.

Figure 5. Chemotransformation of $20 \mathrm{mM}$ DHIQ to DHIO using different ratios of CuI and $\mathrm{H}_{2} \mathrm{O}_{2}$.

Figure 6. Kinetic performance of MAO-N D9 expressed in E. coli OverExpress C43(DE3) cells.

Figure 7. The inhibition effect of 3,4-dihydroisoquinoline (DHIQ) on the biotransformation with $20 \mathrm{mM}$ THIQ.

Figure 8. Two-step chemo-biocatalysis in a one-pot system: Triple substrate feeding during the biological step with initial reaction volume of $25 \mathrm{ml}$ and an initial biomass concentration of $6.83 \mathrm{mg}_{\mathrm{DCw}} / \mathrm{ml}(\mathrm{A})$. Chemical transformation of the biologically produced DHIQ to DHIO (B). 


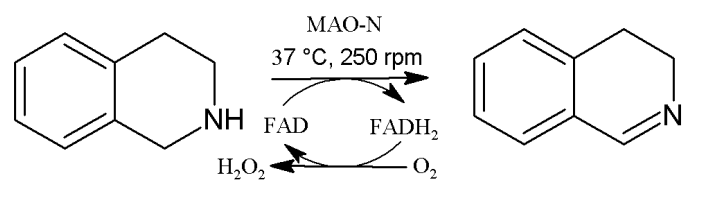

1,2,3,4-tetrahydroisoquinoline

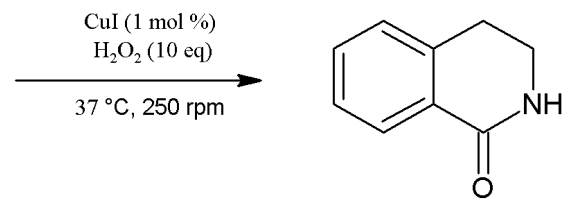

3,4-dihydroisoquinolin-1(2H)-one

Figure 9. 


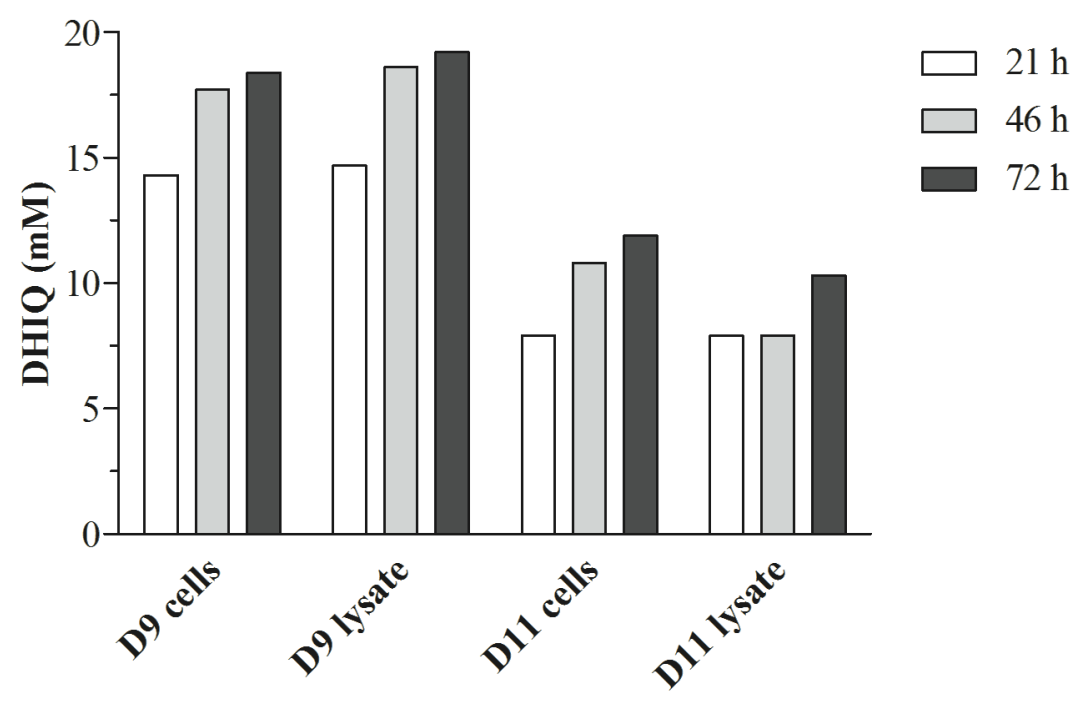

Figure 10. 


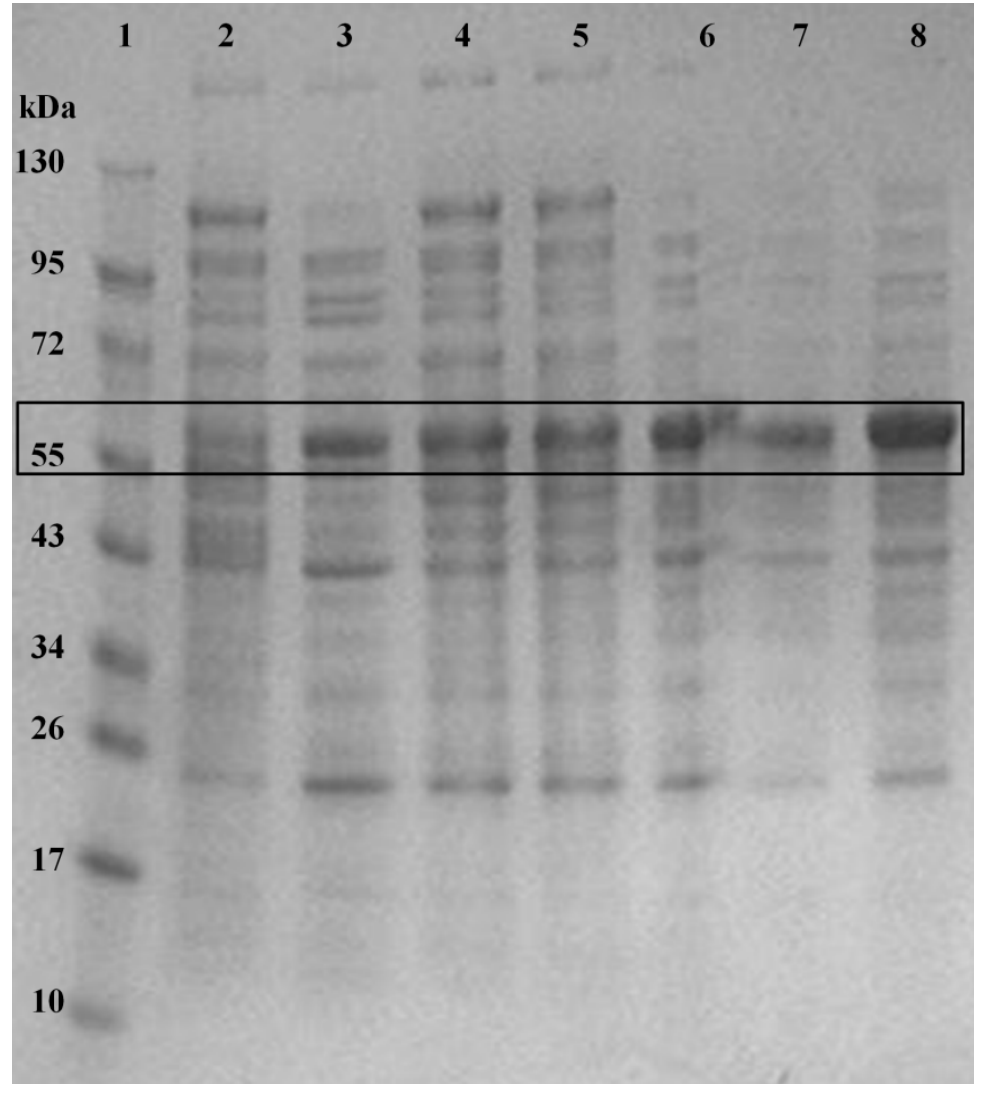

Figure 11. 
A

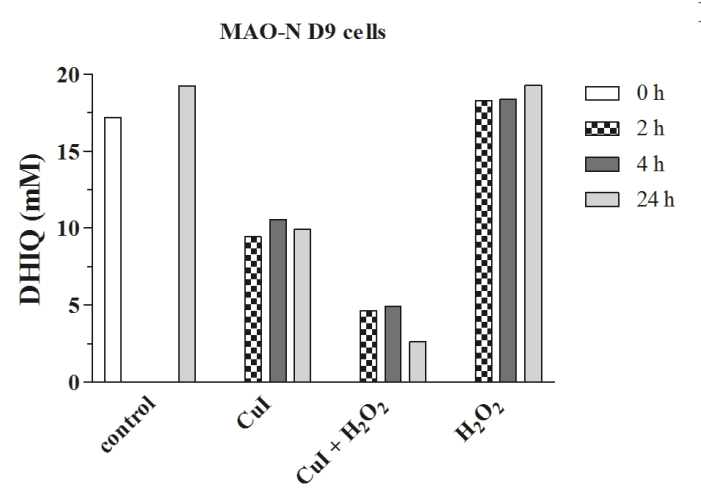

B

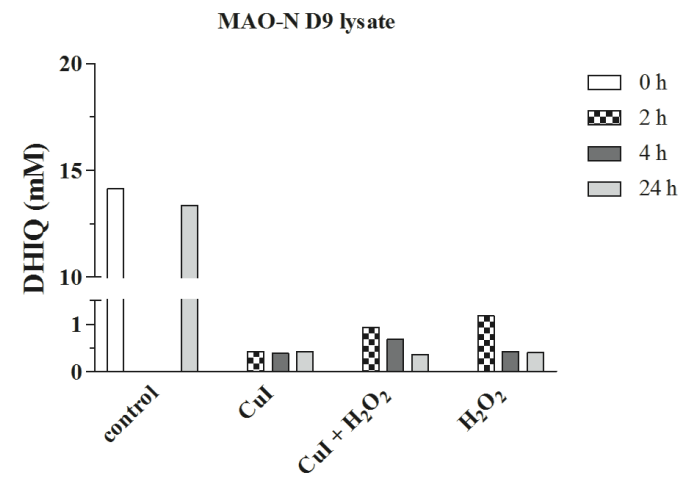

Figure 12. 


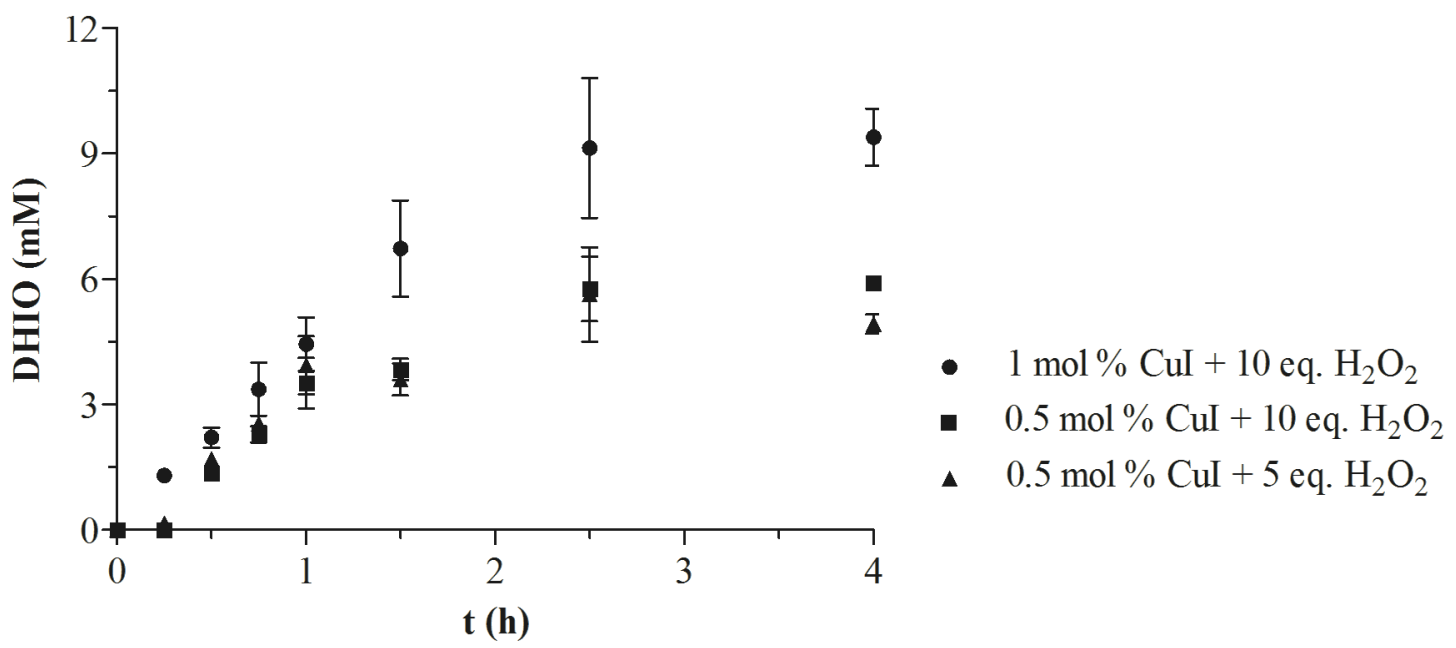

Figure 13. 


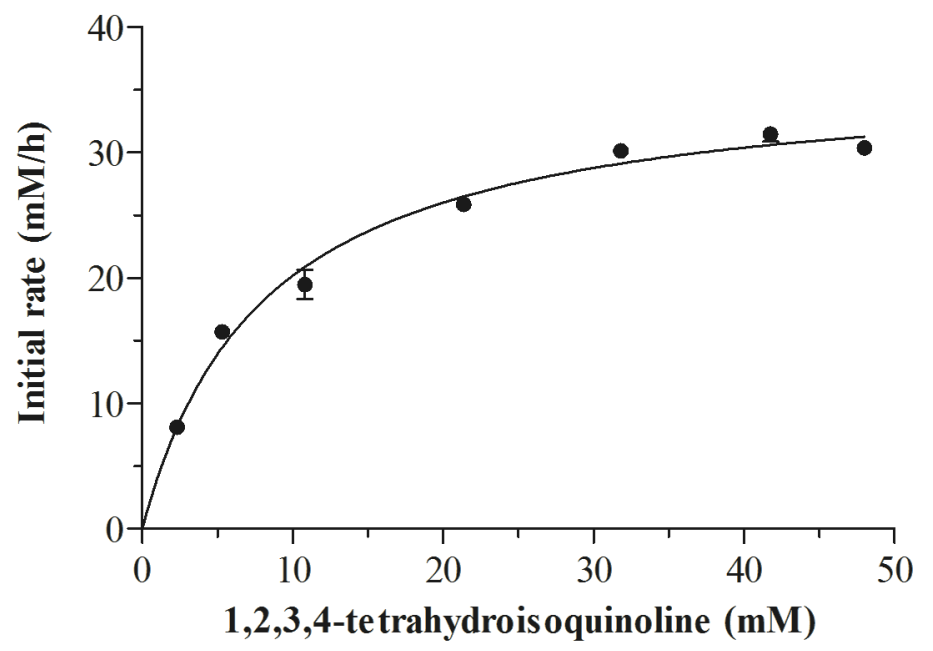

Figure 14. 


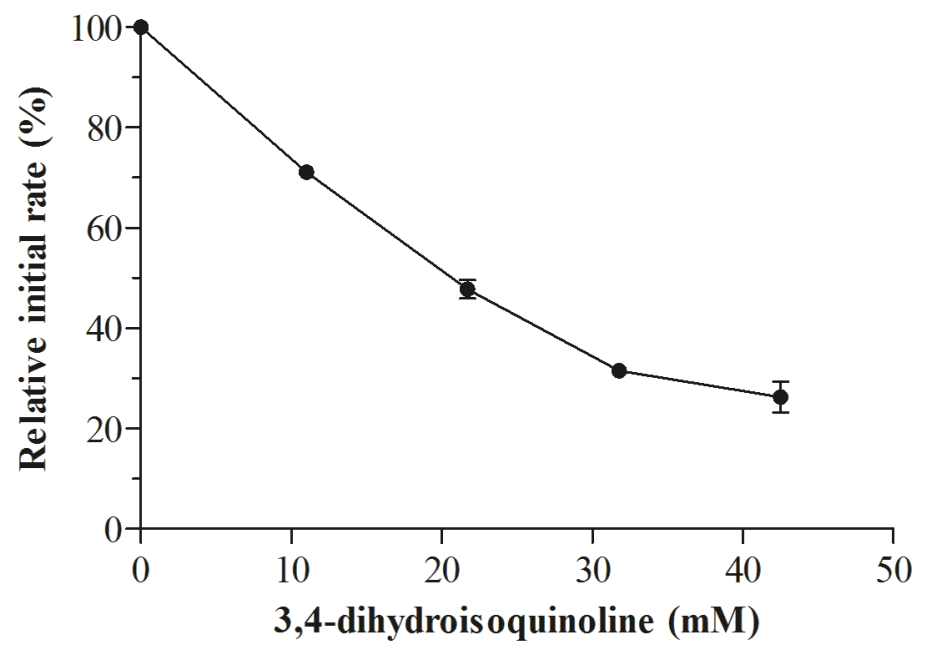

Figure 15. 
A

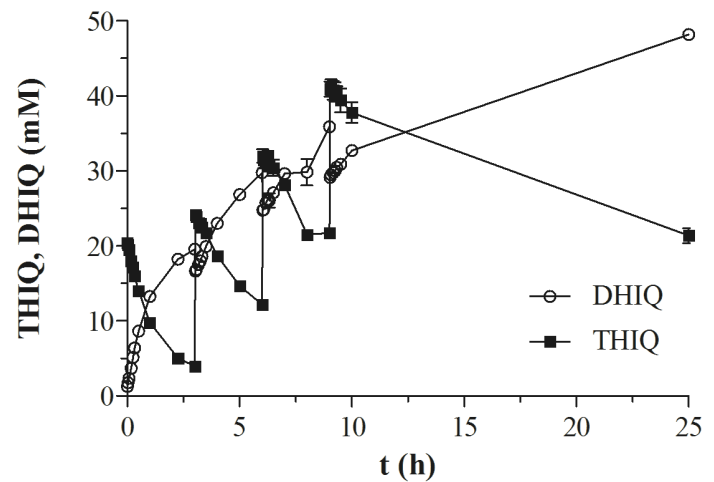

B

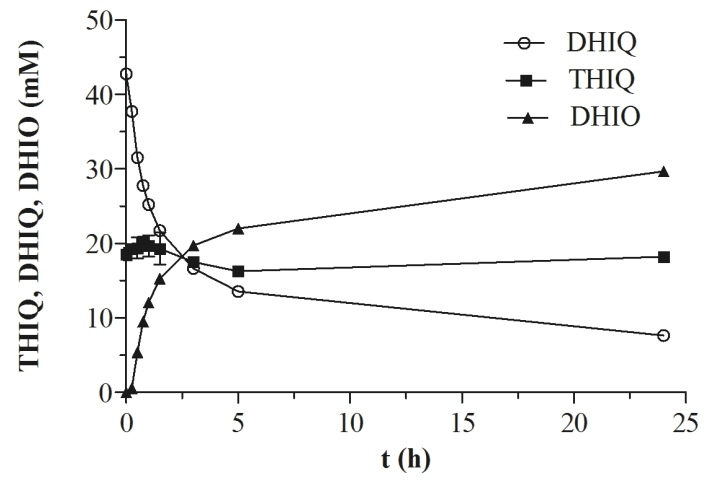

Figure 16. 